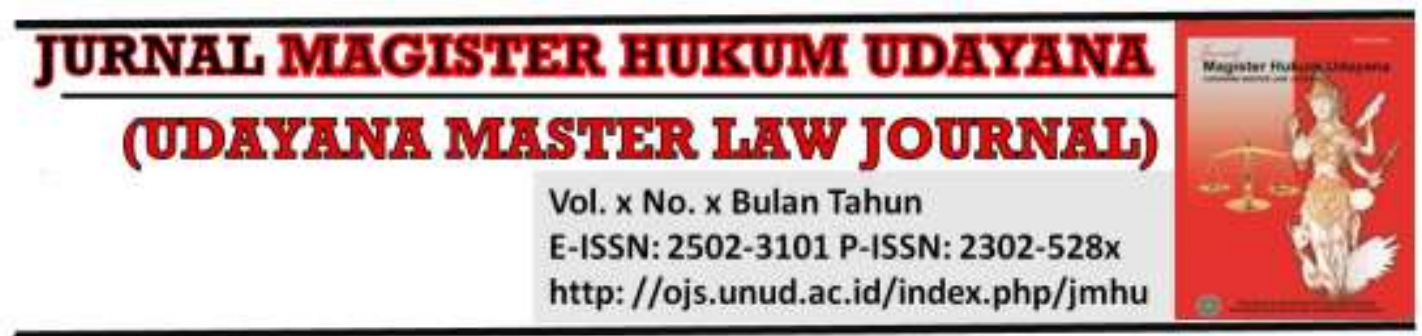

\title{
Eksekusi Pembakaran/Penenggelaman Kapal Tindak Pidana Illegal Fishing Berbendera Asing Dalam Perspektif Sistem Peradilan Pidana
}

\author{
Guntur Dirga Saputra1 \\ ${ }^{1}$ Program Studi Magister Ilmu Hukum, Fakultas Hukum Universitas Udayana, \\ E-mail: gunturdirga@gmail.com
}

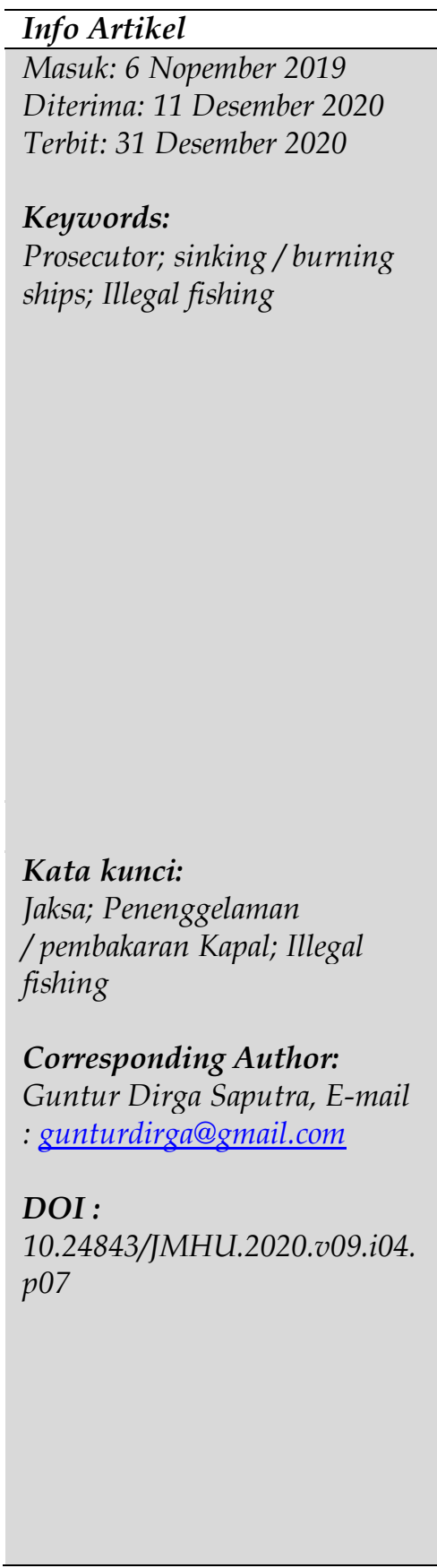

\begin{abstract}
Indonesia's natural resources in the form of very wide waters pose a threat to the crime of illegal fishing. The prevention of these crimes is carried out by giving the investigator authority to sink / burn ships with foreign flags directly without a court decision having permanent legal force as regulated in Law 45/2009. This research is a normative legal research. The results of this writing explain that the sinking / burning of foreign-flagged ships by investigators is contrary to Article 28D Paragraph (1) of the 1945 Constitution which is hierarchically higher than Law 45/2009 and SPP regulated in the Criminal Procedure Code so that it does not provide justice and legal certainty because it has seized the rights of the suspect / defendant. The sinking / burning of the ship is the authority of the Public Prosecutor to carry out the execution after a court decision has permanent legal force which stipulates that evidence in the form of a ship is seized for destruction and is not under the authority of the investigator. The government and the DPR RI should revise Law 45/2009 to revoke the authority of investigators who can directly sink / burn ships and to the Prosecutor to coordinate and involve investigators to become witnesses in the execution.
\end{abstract}

Abstrak
Kekayaan alam Indonesia berupa perairan yang sangat luas
menimbulkan ancaman terjadinya tindak pidana illegal fishing.
Penanggulangan kejahatan tersebut dilakukan dengan memberikan
kewenangan kepada penyidik untuk melakukan
penenggelaman/pembakaran kapal yang berbendera asing yang
secara langsung tanpa putusan pengadilan yang berkekuatan
hukum tetap sebagaimana diatur dalam UU 45/2009. Penelitian
ini merupakan penelitian hukum normatif. Hasil penulisan ini
menjelaskan bahwa Penenggelaman/pembakaran kapal berbendera
asing oleh Penyidik bertentangan dengan Pasal 28D Ayat (1)
UUDNRI 1945 yang secara hirarki lebih tinggi dari UU 45/2009
dan SPP yang diatur dalam KUHAP sehingga tidak memberikan
keadilan dan kepastian hukum oleh karena telah merampas hak
tersangka/terdakwa. Penenggelaman/pembakaran kapal merupakan
kewenangan Jaksa Penuntut Umum untuk melakukan eksekusi
setelah adanya putusan pengadilan yang berkekuatan hukum tetap
yang menetapkan barang bukti berupa kapal untuk dirampas
untuk dimusnahkan dan bukan merupakan kewenangan penyidik.
Pemerintah dengan DPR RI agar melakukan revisi UU 45/2009


untuk mencabut kewenangan penyidik yang secara langsung dapat melakukan penenggelaman/pembakaran kapal dan kepada Jaksa agar melakukan kordinasi dan melibatkan penyidik untuk menjadi saksi dalam pelaksanaan eksekusi.

\section{Pendahuluan}

Indonesia adalah negara maritim dengan luas Zona Ekonomi Eksklusif 7,81 juta km². Wilayah lautan Indonesia yang luas adalah suatu kekayaan yang dimiliki oleh Indonesia yang mana isi lautan tersebut merupakan kualitas terbaik mulai dari terumbu karang, tumbuhan laut, hasil ikan, udang serta hewan lainnya sehingga memiliki nilai ekonomis yang sangat tinggi. ${ }^{1}$ Kekayaan lautan Indonesia tersebut dapat dimanfaatkan oleh rakyat Indonesia khususnya untuk memenuhi kebutuhan hidup para nelayan untuk memenuhi kebutuhan dalam negeri maupun untuk kebutuhan ekspor dan hasil-hasil laut lainnya ke mancanegara. Oleh karena itu, besarnya hasil laut yang diperoleh akan menjadi aset yang sangat berharga bagi kesejahteraan masyarakat yang dimanfaatkan dengan maksimal, maka dapat memberikan pendapatan sejumlah 1,2 triliun dollar AS per tahun untuk Negara. ${ }^{2}$

Lautan Indonesia yang sangat kaya disisi lain memiliki ancaman yakni terjadinya tindak pidana illegal fishing. Istilah illegal fishing berasal dari kata "illegal" yang artinya "tidak sah" dan "fishing" yang artinya perikanan. Dengan demikian illegal fishing berarti kegiatan yang berkaitan dengan perikanan yang dilakukan dengan tidak sah. ${ }^{3}$ Dalam Undang-Undang Republik Indonesia Nomor 45 Tahun 2009 tentang Perubahan atas Undang-Undang Republik Indonesia Nomor 31 Tahun 2004 tentang Perikanan (yang kemudian disingkat UU 45/2009) terdapat istilah illegal fishing namun tidak menjelaskan pengertian dari illegal fishing tersebut.

Tindak pidana illegal fishing saat ini mengalami perubahan menjadi tindak pidana $a$ highly sophisticated form of transnational organized crime yang memiliki tipologi kontrol pergerakan kapal serta peralatan modern. ${ }^{4}$ Tindak pidana Illegal fishing mengakibatkan kerugian terhadap para nelayan yang mengalami kerugian oleh karena berkurangnya pendapatan dalam mencari hasil laut oleh karena para pelaku tindak pidana illegal fishing mencari hasil laut dengan cara yang tidak sah tanpa memperhatikan dampak lingkungan berkelanjutan dan ekosistem laut yang ada. Selain itu, dampak dari tindak pidana illegal fishing juga mempengaruhi perekonomian negara dalam lingkup makro. Banyaknya hasil laut yang dicuri oleh para pelaku tindak pidana illegal fishing

1 Elviana Roza. (2017). Maritim Indonesia, Kemewahan Yang Luar Biasa. URL: http://www2.kkp.go.id/artikel/2233-maritim-indonesia-kemewahan-yang-luar-biasa. (diakses 05 September 2019).

2 Budi Prasetyo. (2019) Laut Indonesia Dapat Menyumbang Pendapatan 1,2 Triliun Dollar AS. URL:https://www.kompas.com/ekonomi/read/2014/08/11/133800526/Laut.Indonesia.Dap at.Menyumbang.Pendapatan.1.2.Triliun.Dollar.AS (Diakses 29 Juni 2019).

3 Mahmudah N. (2015). Illegal Fishing Pertanggungjawaban Pidana Korporasi di Wilayah Perairan Indonesia. Jakarta: Sinar Grafika, h. 80.

4 Fernandes, I. (2017). Tinjauan Yuridis Illegal Fishing di Indonesia Berdasarkan UndangUndang Perikanan. Jurnal Hukum Respublica, 17(1), 189-209.h. 193. 
mengakibatkan menurunnya pendapatan negara yang mana dari data Badan Pangan Dunia,Indonesia mengalami kerugian per tahun sejumlah 30 triliun rupiah. ${ }^{5}$

Pemerintah dalam memberantas tindak pidana illegal fishing menerapkan kebijakan pembakaran/penenggelaman terhadap kapal tindak pidana illegal fishing berbendera asing hanya berdasarkan bukti permulaan yang cukup yang saat ini diyakini menjadi solusi untuk keluar dari persoalan tersebut. Kebijakan tersebut dilakukan berdasarkan Pasal 69 ayat (4) UU UU 45/2009 mengatur bahwa "dalam melaksanakan fungsi sebagaimana dimaksud dalam ayat (1) penyidik dan/atau pengawas perikanan dapat melakukan tindakan khusus berupa pembakaran dan/atau penenggelaman kapal perikanan yang berbendera asing berdasarkan bukti permulaan cukup". Hal tersebut berarti meskipun tidak adanya faktor yang membahayakan dalam penangkapan kapal tindak pidana illegal fisihing, penyidik ataupun pengawas perikanan dapat secara langsung melaksanakan pembakaran atau menenggelamkan kapal milik pelaku tindak pidana illegal fishing berbendera asing tanpa disertai proses peradilan dan putusan pengadilan yang berkekuatan hukum tetap. Pembocoran pada dinding kapal, membuka keran laut yang terdapat pada kapal, diledakkan atau dibakar merupakan beberapa cara untuk melakukan penenggelaman atau pembakaran pada kapal tindak pidana illegal fishing berbendera asing. ${ }^{6}$

Pembakaran/penenggelaman kapal tindak pidana illegal fishing berbendera asing tersebut dalam perspektif sistem peradilan pidana (yang kemudian disingkat SPP) belum mewujudkan Due Process of Law atau hukum acara yang benar dan berkeadilan oleh karena tanpa melalui putusan peradilan yang telah memperoleh kekuatan hukum tetap. Kapasitas negara untuk melakukan eksekusi tanpa suatu justifikasi hukum menimbulkan suatu permasalahan, sebab Indonesia merupakan negara hukum yang wajib mematuhi Due Process of Law.

Negara hukum wajib menerapkan sistem hukum secara murni dan menyeluruh sehingga tercapainya keadilan dan kepastian bagi seluruh lapisan masyarakat yang di dalamnya terdapat individu-individu yang setiap hak-haknya harus di lindungi oleh negara. Namun, dengan diabaikannya Due Process of Law oleh para negara dalam penegakkan hukum maka telah tercipta suatu pelanggaran terhadap norma-norma dasar yang secara De Jure telah di tentukan oleh ketentuan perundang-undangan. SPP telah dirumuskan secara ideal oleh perumus undang-undang dengan cara melaksanakan Due Process of Law terutama dalam setiap bagian penegakan hukum. Pasal 1 butir 1 Jo. Pasal 1 butir 2 Undang-Undang Republik Indonesia Nomor 8 Tahun 1981 Tentang Hukum Acara Pidana (yang kemudian disingkat KUHAP), bahwa yang dimaksud penyidik adalah pejabat Polri atau pejabat PNS tertentu yang diberi kewenangan untuk melakukan penyidikan sehingga penyidik tidak memiliki kewenangan sebagai eksekutor untuk melaksanakan eksekusi. Eksekusi terhadap kapal tersebut juga tidak memiliki urgensi sehingga harus dilakukan dengan segera

5 Wij, Menteri Susi: Kerugian Akibat Illegal Fishing $\mathrm{Rp} 240$ Triliun. URL: https://m.detik.com/finance/berita-ekonomi-bisnis/d-2764211/menteri-susi-kerugianakibat-illegal-fishing-rp-240-triliun (Diakses 29 Juni 2019).

${ }^{6}$ Haryanto, H., \& Setiyono, J. KEBIJAKAN PENENGGELAMAN KAPAL ASING PELAKU ILLEGAL FISHING OLEH PEMERINTAH INDONESIA DALAM PERSFEKTIF HUKUM PIDANA INTERNASIONAL. LAW REFORM, 13(1), 70-85. h. 74. 
tanpa dapat menunggu putusan pengadilan yang berkekuatan hukum tetap yang mana dalam amar putusan menetapkan kepada Jaksa Penuntut Umum selaku eksekutor untuk melakukan pemusnahan terhadap kapal tersebut yang dapat dilakukan dengan cara ditenggelamkan atau dibakar. Berdasarkan uraian tersebut, maka pembakaran/penenggelaman kapal tindak pidana illegal fishing tanpa disertai putusan pengadilan yang telah memperoleh kekuatan hukum tetap dan dilakukan oleh penyidik PNS merupakan konflik norma hukum dalam SPP di Indonesia sebagaimana yang diatur dalam KUHAP.

\section{Metode Penelitian}

Dalam penelitian hukum ini menggunakan metode penelitian normatif yang mana norma hukum yang termuat dalam peraturan perundang-undangan dikonsepkan sebagai pedoman manusia dalam berprilaku secara pantas. ${ }^{7}$ Penelitian hukum normatif dilakukan oleh karena adanya konflik norma hukum mengenai eksekusi pembakaran/penenggelaman kapal pelaku illegal fishing tanpa putusan pengadilan sebagaimana yang diatur dalam UU 45/2009 dan dilakukan oleh KKP selaku penyidik PNS bertentangan dengan sistem peradilan pidana yang dianut di Indonesia sebagaimana yang diatur dalam KUHAP sehingga diperlukan harmonisasi terhadap UU 45/2009. Jenis pendekatan yang digunakan yakni statute approach terhadap undang - undang, SEMA, dan peraturan Menteri terkait dengan tindak pidana illegal fishing dan conceptual approach melalui konsep dan/atau teori hukum terkait isu tersebut.

Bahan hukum yang digunakan untuk menganalisa guna memecahkan masalah yakni bahan hukum primer terkait statue approach yang digunakan serta SPP dan bahan sekunder yakni buku, jurnal, serta bahan hukum lainnya yakni berupa situs internet yang telah memenuhi syarat serta dapat dipertanggungjawabkan mengenai kebenarannya yang terkait dengan permasalahan tersebut. Bahan hukum primer dikumpulkan, disusun, serta dianalisa dengan menggunakan teknik sistematisasi melalui metode bola salju yang ada kaitannya dengan isu yang dibahas yang sebelumnya telah diklasifikasikan mengenai peraturan yang masih berlaku, secara hirarki lebih tinggi dan rendah, dan yang bersifat khusus dan umum. Bahan hukum sekunder dikumpulkan dengan menggunakan teknik bola salju yang dilakukan dengan mencantumkan kutipan pada catatan kaki dan daftar pustaka lalu menggelinding mencari bahan hukum sekunder yang termuat dalam daftar pustaka bahan hukum sekunder yang dikutip tersebut lalu berhenti hinggal literatur yang diperlukan sudah cukup.

Bahan hukum sebagaimana diuraikan di atas dianalisa dengan menggunakan 4 (empat) yakni teknik deskriptif untuk menguraikan persititwa hukum mengenai penenggeleman/pembakaran kapal; teknik komparatif untuk membandingkan norma hukum yang mengatur mengenai penenggelaman/pembakaran kapal dengan norma hukum mengenai SPP; teknik evaluatif untuk memberikan dasar dalam menerima atau menolak mengenai kebijakan penenggelaman/pembakaran kapal; dan teknik argumentatif untuk memberikan argumentasi peneliti mengenai kebijakan penenggelaman/pembakaran kapal dimasa yang akan datang.

7 Amirudin dan Zainal Asikin. (2012). Pengantar Metode Penelitian Hukum, Jakarta: Rajawali Pers, h. 118. 


\section{Hasil dan Pembahasan}

\subsection{Pembakaran/Penenggelaman Kapal Tindak Pidana Illegal Fishing Dalam Sistem Peradilan Pidana}

Pasal 1 ayat 3 Undang-Undang Dasar Negara Republik Indonesia Tahun 1945 (yang kemudian disingkat UUD NRI 1945), diatur bahwa "Indonesia adalah negara hukum", sehingga segala bentuk tindakan / kebijakan Negara harus berdasarkan pada peraturan perundang-undangan termasuk diantaranya pembakaran/penenggelaman kapal tindak pidana llegal fishing. Pasal 69 ayat (4) Juncto Pasal 76A jo. Pasal 38 UU 45/2009 merupakan dasar hukum Pemerintah dalam melakukan kebijakan untuk membakar atau menenggelamkan kapal oleh karena dalam pasal tersebut memberikan kewenangan kepada penyidik dan/atau pengawas perikanan untuk membakar dan/atau menenggelamkan kapal illegal fishing berbendera asing berdasarkan bukti permulaan yang cukup. Ketentuan tersebut berarti apabila adanya laporan maupun tertangkap tangan, pembakaran/penenggelaman kapal dapat langsung dilakukan oleh penyidik dan/atau pengawas perikanan seluas-luasnya tanpa perlu putusan pengadilan yang berkekuatan hukum tetap tanpa adanya batasan dan syarat yang jelas yang harus dipenuhi yang mana hanya cukup dengan adanya bukti permulaan.

Ketentuan dalam UU 45/2009 yang memberikan kewenangan yang luas kepada penyidik dan/atau pengawas perikanan untuk melakukan eksekusi pembakaran/penenggelaman kapal hanya berdasarkan bukti permulaan yang cukup namun dalam Peraturan Menteri Kelautan dan Perikanan Republik Indonesia Nomor 37/PERMEN-KP/2017 tentang Standar Operasional Prosedur Penegakan Hukum Satuan Tugas Pemberantasan Penangkapan Ikan Secara Ilegal (Illegal Fishing) (yang kemudian disingkat Permenkkp 37/2017) sebagai peraturan pelaksana memberikan syarat yang harus dipenuhi dalam melakukan kebijakan tersebut yakni syarat subjektif berupa kapal yang bermanuver membahayakan atau memberikan perlawanan serta syarat objektif yang terdiri dari syarat kumulatif yakni kapal berbendera asing; locus delicti di wilayah pengelolaan perikanan Indonesia; tidak adanya dokumen; dilaksanakan dengan hati-hati dan atas perintah pimpinan, dan syarat alternatif yakni kapal tua yang tidak memiliki nilai ekonomis; kapal mudah rusak atau membahayakan; biaya penarikan yang tinggi; kapal mengangkut barang yang mengandung penyakit menular atau bahan beracun dan berbahaya.

Surat Edar Mahkamah Agung Republik Indonesia Nomor 1 Tahun 2015 tentang Barang Bukti Kapal Dalam Perkara Pidana Perikanan (yang kemudian disingkat SEMA1/2015), mendukung pemerintah melakukan tindakan tersebut. Oleh sebab itu, maka barang bukti kapal dapat ditenggelamkan atau dimusnahkan. Dengan berpedoman pada peraturan perundang-undangan diatas, maka penyidik/pengawas perikanan dapat melakukan eksekusi pidana pembakaran/penenggelaman kapal 
tanpa proses hukum adalah hal yang patut. ${ }^{8}$ Hal tersebut dilakukan seperti kapal berbendera asing yang tidak memiliki SIPI, SIKPI, serta WPP-RI. ${ }^{9}$

Pengakuan terhadap HAM merupakan salah satu unsur yang terpenting dalam negara hukum. Pengaturan HAM dalam UUD NRI 1945 memberikan kebebasan yang dibatasi dengan undang-undang. HAM yang dijamin dan diatur oleh sistem hukum Indonesia tidak bersifat mutlak/ dibatasi apabila penggunaan daripada HAM tersebut telah merusak dan merenggut HAM orang lain. Penelaahan terhadap tujuan hukum perlu dilakukan sebelum dapat mewujudkan Negara hukum melalui pembentukan undangundang. Gustav Radbruch berpendapat bahwa hukum ditujukan untuk menciptakan suatu keadilan, kemanfaatan, dan kepastian hukum secara sinergi bersama-sama yang apabila dalam penerapannya tidak dapat dilaksanakan maka harus memprioritaskan keadilan baru kemudian kemanfaatan lalu kepastian hukum. ${ }^{10}$ Inti pendapat sebagaimana di jelaskan oleh Radbruch bahwa sesungguhnya baik keadilan, kepastian, ataupun kemanfaatan dapat hidup sebagai tujuan hukum yang ada dalam satu sistem hukum secara bersama dan maksimal dalam suatu totalitas. 3 (tiga) tujuan hukum tersebut belum tentu dapat diwujudkan secara bersama, oleh karena itu maka harus diambil skala prioritas dalam mewujudkan tujuan hukum yakni dengan mempriortaskan kemanfaatan, lalu keadilan, dan kemudian kepastian hukum. ${ }^{11}$ Berkaitan dengan pendapat Radbruch tersebut, Herbert Leonel Hart berpendapat bahwa keadilan akan memberikan manfaat apabila ditegakkan oleh kepastian, sehingga tujuan hukum yang mutlak akan terwujud apabila di dasarkan kepada ketiga konsep tersebut secara keseluruhan.

Indonesia sebagai negara hukum sebagaimana dijelaskan di atas, harus selalu memusatkan sistem hukum pada prinsip-prinsip dasar yang terpenting tanpa mengurangi esensinya sedikitpun. ${ }^{12}$ Negara hukum memiliki tujuan tertinggi untuk mencapai semua dari semua norma-norma dasar berupa moral dan etika yang ditunjukkan dengan penegakan Hak Asasi Manusia. Penerapan Crime Control Model (CCM) bersama dengan Due Process Model (DPM) yang pengaturannya diatur dalam KUHAP merupakan implementasi dari penegakkan HAM sebagaimana yang diatur dalam Pasal 28D Ayat (1) UUDNRI 1945 yang mengatur bahwa setiap orang berhak untuk mendapatkan pengakuan, jaminan, perlindungan, dan kepastian hukum yang adil serta perlakukan yang sama dihadapan hukum. Original Intent dari negara hukum Indonesia adalah pemenuhan semua hal tersebut tanpa pengurangan sedikitpun akan prinsip dasar, oleh karena itu maka semua kekurangan dalam sistem hukum yang bertentangan dengan prinsip-prinsip tersebut harus diperhatikan dan diperbaiki. Herbert L. Packer mengemukakan bahwa SPP yang melindungi HAM yakni adanya sistem penegakkan hukum yang berimbang antara DPM (hak-hak pelanggar hukum

8 Pasopati, G. Setahun jadi Menteri Susi Tenggelamkan Kapal Tanpa Diadili. URL: https://www.cnnindonesia.com/ekonomi/20151020121906-92-86037/setahun-jadi-menterisusi-tenggelamkan-kapal-tanpa-diadili. (Diakses 29 Juni 2019).

9 Saraswati, D. A., \& Setiyono, J. YURISDIKSI KRIMINAL NEGARA DALAM PENENGGELAMAN KAPAL PELAKU TINDAK PIDANA ILLEGAL FISHING DI PERAIRAN INDONESIA. LAW REFORM, 13(2), 180-188. h. 185.

${ }^{10}$ Nurul Qamar. (2010). Hukum Itu Ada Tapi Harus Ditemukan. Makassar: Pustaka Refleksi, h. 12.

11 Achmad Ali, (2002). Menguak Tabir Hukum: Suatu Kajian Filosofis dan Sosiologis. Jakarta: Gunung Mas, h. 95.

12 Sukriono, D. (2010). Hukum, Konstitusi dan Otonomi. Malang: Setara Press, h. 43. 
tetap diakomodiir) dan CCM (penekanan pada penghukuman pelanggar hukum sebagai bentuk pemenuhan hak masyarakat yang sudah dirampas haknya oleh pelanggar hukum). ${ }^{13}$

SPP merupakan sarana yang memiliki fungsi untuk menegakkan hukum. ${ }^{14}$ Original Intent yang Indonesia sebagai negara hukum dalam SPP adalah diterapkannya DPM dan CCM dalam SPP sehingga tercapainya keadilan dan kepastian bagi seluruh lapisan masyarakat yang di dalamnya terdapat individu-individu yang setiap hak-haknya harus di lindungi oleh negara. Penerapan Due Process of Law oleh para penegak hukum merupakan suatu prinsip yang fundamental dalam penegakkan norma-norma dasar yang secara De Jure. SPP yang telah dirumuskan dengan memasukkan CCM bersama $D P M$ sebagai dua sistem hidup berkesinambungan dan melengkapi satu sama lain, tetapi apabila aparat penegak hukum hanya memperhatikan CCM saja maka sistem menjadi berat sebelah dan menjadi cacat. Ergo untuk menciptakan kembali sistem hukum yang sesuai dengan Original Intent maka harus DPM bersama dengan CCM diimplementasikan keduanya secara mutlak oleh aparat penegak hukum.

Kebijakan penenggalaman kapal yang dilakukan saat ini dengan menunjukkan hanya menerapkan CCM. ${ }^{15}$ Praktik penenggalaman kapal tersebut mendapat dukungan dari masyarakat Indonesia yang mengganggap bahwa kebijakan ini adalah baik. ${ }^{16}$ Pembakaran/penenggelaman kapal merupakan kebijakan yang tepat untuk dilakukan meskipun disisi lain terdapat nilai ekonomis apabila kapal tersebut dirampas untuk Negara untuk dijual maupun untuk dikelola oleh kelompok negara sehingga dapat memberikan kemanfaatan yang sangat luas untuk Negara. Kemanfaatan dalam pembakaran/penenggelaman kapal yang dinilai tindakan yang keras (shock terapy) tentu harus tetap dilakukan untuk manfaat yang lebih luas agar memberikan efek jera kepada pelaku serta mencegah terjadinya illegal fishing kembali sehingga terwujudnya kedaulatan di wilayah perairan NKRI. Terlepas daripada pro kontra, penenggelaman kapal diharapkan dapat membangun kedaulatan yang mampu menopang kemandirian ekonomi dalam pengelolaan sumber daya kelautan dan perikanan. ${ }^{17}$ Penenggelaman/pembakaran kapal meskipun telah memberikan kemanfaatan namun belum memberikan keadilan dan kepastian hukum kepada pelaku sebagaimana yang dikemukakan oleh Gustav Radbruch oleh karena tidak dilaksanakan tanpa proses adjudikasi dan berdasarkan pada putusan pengadilan yang berkekuatan hukum tetap sehingga telah merampas hak-hak tersangka/terdakwa sebagaimana yang diatur di KUHAP.

${ }^{13}$ Barama, M. (2016). Model Sistem Peradilan Pidana Dalam Perkembangan. Jurnal Ilmu Hukum, 3(8), 8-17. h. 10.

${ }^{14}$ Ali, M. (2007). Sistem Peradilan Pidana Progresif; Alternatif dalam Penegakan Hukum Pidana. Jurnal Hukum Ius Quia Iustum, 14(2). h. 211.

${ }_{15}$ Putri, H. M., Pramoda, R., \& Firdaus, M. (2018). Kebijakan Penenggelaman Kapal Pencuri Ikan Di Wilayah Perairan Indonesia Dalam Perspektif Hukum. Jurnal Kebijakan Sosial Ekonomi Kelautan dan Perikanan, 7(2), 91-102. hlm. 41.

${ }^{16}$ Rahman, Z., \& Republik, N. K. (2015). Penenggelaman Kapal Sebagai Usaha Memberantas Praktik Illegal Fishing. Rechts Vinding Online,(Januari, 2015). h. 37.

${ }^{17}$ Nasirin, C., \& Hermawan, D. (2017). Kontroversi Implementasi Kebijakan Penenggelaman Kapal Dalam Rangka Pemberantasan Illegal Fishing di Indonesia. Spirit Publik, 12(1), 9-24.h. 15. 
Kebijakan penenggelaman/pembakaran kapal dalam sudut pandang hukum pidana internasional dapat dibenarkan. Teori kedaulatan negara memiliki pandangan bahwa NKRI sebagai negara kepulauan memiliki kedaulatan atas wilayahnya termasuk dalam penegakan hukum di laut demi kedaulatan secara ekonomi dari gangguan asing sehingga penenggelaman/pembakaran kapal merupakan pelaksanaan kewenangan terhadap pelanggaran kedaulatan terhadap pelaku berkewarganegaraan asing yang mana pemidanaan dalam bentuk apapun yang dijatuhkan dalam putusan pidana tidak dapat diganggu gugat oleh kekuasaan pemerintaana di luar lingkup badan peradilan (upaya hukum). Teori yurisdiksi kriminal dalam hukum pidana internasional berpandangan bahwa hukum internasional memberikan yurisdiksi kepada negara karena memiliki kedaulatan atau kekuasaan tertinggi sehingga berwenang untuk mengatur masalah ekstern maupun intern termasuk diantaranya wilayah perairan. Kebijakan penenggelaman/pembakaran kapal pada prinsipnya merupakan penerapakn yurisdiksi kriminal Indonesia dalam menerapkan yurisdiksi terhadap zona atau wilayah yang oleh UNCLOS 1982 status hukumnya disebut dengan kewenangan (yurisdiksi) suatu negara sehingga kebijakan tersebut merupakanpenerapan yurisdiksi kriminal berdasarkan prinsip teritorial dan ekstrateritorial. Teori penegakan hukum pidana interansional berpandangan bahwa kebijakan penenggelaman/pembakaran kapal merupakan penegakan hukum pidna internasioanl sesuai dengan prosedur indirect enforcement system yaitu upaya mengajukan tuntutan dan peradilan terhadap para pelaku tindak pidana internasional melalui undang-undang nasional. Penegakan hukum pidana internasional tersebut dilakukan berupa pemusnahan barang bukti kapal perikanan, hal ini berarti mengisyaratkan harus adanya proses hukum yang dilalui sebelum pelaksanaan penenggelaman/pembakaran kapal berbendera asing. ${ }^{18}$ Penenggelaman/pembakaran kapal yang melalui proses hukum mengakibatkan Indonesia memiliki landasan hukum dalam menerapkan kebijakan tersebut namun apabila tidak dilalui proses adjudikasi maka Indonesia tidak memiliki landasan hukum internasional yang kuat sehingga dapat mengakibatkan adanya gugatan atau keberatan dari negara asing.

Undang-undang terikat dengan asas lex superior derigat legi inferiori yang berarti bahwa hukum yang kedudukannya lebih rendah tidak boleh bertentangan dengan hukum yang lebih tinggi. ${ }^{19}$ KUHAP yang memuat Crime Control Model (CCM) bersama dengan Due Process Model (DPM) yang merupakan implementasi Pasal 28D Ayat (1) UUDNRI 1945 sehingga apabila penenggelaman/pembakaran kapal dilakukan tanpa adanya putusan pengadilan yang berkekuatan hukum tetap bertentangan dengan Pasal 28D Ayat (1) UUDRNRI 1945 oleh karena tidak memberikan kesempatan yang sama dimuka hukum kepada pelaku yang mana dalam KUHAP diatur mengenai hak-hak tersangka/terdakwa serta akibat hukum terhadap benda yang dipergunakan dalam melakukan tindak pidana.

Pembakaran/penenggelaman kapal tanpa didasarkan pada putusan pengadilan yang berkekuatan hukum tetap tidak mewujudkan Due Process of Law yang mana harus

${ }^{18}$ Haryanto dan Joko Setiyono, (2017). Kebijakan Penenggelaman Kapal Asing Pelaku Illegal fishing oleh Pemerintah Indoensia Dalam Perspektif Hukum Pidana Internasional, Jurnal Law Reform Vol. 13 No. 1, h. 77-81.

${ }^{19}$ Bo'a, F. Y. (2018). Pancasila sebagai Sumber Hukum dalam Sistem Hukum Nasional. Jurnal Konstitusi, 15(1), 21-49. h. 46. 
ditegakkannya jaminan terhadap keadilan dan kepastian hukum namun terdapat celah-celah hukum yang mencederai prosedur hukum ideal yang dicita-citakan. ${ }^{20}$ Kebijakan pembakaran/penenggelaman kapal tidak boleh dilakukan semata-mata hanya untuk upaya "balas dendam" atau "unjuk kekuatan" tanpa memiliki justifikasi dalam SPP melainkan harus sesuai dengan SPP yang didalamnya terdapat paradigma berpikir DPM dan CCM. Hak seorang terdakwa/tersangka tidak akan terlindung dalam sistem yang mengedepankan CCM, sebab proses pemidanaan KUHAP didasarkan pada fakta dan alat bukti dalam pemeriksaan di persidangan.

Pembakaran/penenggelaman kapal pelaku tindak pidana illegal fishing tidak boleh dilakukan secara sewenang-wenang melainkan harus melalui proses yudisial sesuai yang diatur dalam KUHAP. UU 45/2009 hanya memberikan ketentuan dengan adanya bukti permulaan yang cukup maka penyidik dan/atau pengawas perikanan dapat melakukan pembakaran/penenggelaman kapal. Kewenangan tersebut tentu tidak memberikan keadilan kepada pelaku oleh karena telah merampas hak pelaku untuk melakukan pembelaan diri oleh karena tidak dilakukannya proses adjudikasi terlebih dahulu sebelum dilakukannya penenggelaman/pembakaran kapal tersebut. Ketentuan pasal tersebut juga tidak memberikan kepastian hukum oleh karena dapat dimungkinkan adanya kesewenang-wenangan dalam melakukan penggelaman/pembakaran kapal oleh karena bukti permulaan yang cukup saja tidak dapat menyatakan seseorang bersalah dan hanya hakim yang dapat menyatakan seseorang telah terbukti secara sah dan meyakinkan bersalah melakukan tindak pidana sehingga dijatuhi pidana sebagaimana diatur dalam Pasal 183 KUHAP. Agus Santoso mengemukakan bahwa pemberlakukan aturan tersebut adalah bukti kecacatan SPP sebab terkesan memberlakukan kembali CCM. Kecacatan ini berdampak pada diabaikannya hak-hak para tersangka dan membuka celah kesewenang-wenangan law enforcer, sebab asas yang diterapakan adalah presumption of guilt. ${ }^{21}$

SPP yang ideal adalah gabungan antara Due Process of Law dengan CCM baik dalam hukum yang tertulis dan (yang terpenting) dalam implementasi oleh penegak hukum. Sebab hanya hukum yang cacat yang hanya menekankan pada CCM. SPP yang yang ideal dalam tindak pidana illegal fishing adalah dengan menjatuhkan pidana terhadap pelaku dan barang bukti berupa kapal yang digunakan harus ditenggelamkan/dibakar sebagai implementasi dari CCM namun dalam pelaksanaannya harus tetap mengedepankan asas praduga tak bersalah (presumption of innocence) sehingga tetap memberikan hak tersangka/terdakwa dengan melakukan proses adjudikasi dalam menjatuhkan pidana dan melakukan penenggelaman/pembakaran kapal sebagai implementasi dari DPM. Pemberian kewenangan untuk menindak dengan membakar/meledakkan kapal sama saja dengan memberikan diskresi yang terlampau luas kepada aparat penegak hukum dan/atau penyidik.

Ketentuan yang menyimpang dalam suatu undang-undang dengan undang-undang lainnya merupakan asas lex specialis derogat legi generalis yang mana ketentuan dalam undang-undang khusus dapat mengesampingkan ketentuan yang ada dalam undangundang umum. Penenggelaman/pembakaran kapal yang dilakukan secara langsung

20 Adji, S. (2015). Perkembangan dan Permasalahan Hukum Indonesia. Jakarta: Diadit Media, h. 15.

${ }^{21}$ Agus Susanto, (2014). Hukum, Moral dan Keadilan. Jakarta: Prenada Media, h. 84. 
oleh penyidik dan/atau pengawas perikanan tanpa berdasarkan putusan pengadilan telah menyimpang dari ketentuan Crime Control Model (CCM) bersama dengan Due Process Model (DPM) yang diatur dalam KUHAP namun bukan berarti ketentuan yang menyimpang terhadap tindak pidana illegal fishing tersebut merupakan lex specialias dari KUHAP sehingga dapat mengesampingkan ketentuan KUHAP yang merupakan ketentuan umum. Pengaturan lex specialis tidak secara mutlak dapat mengesampingkan lex generalis melainkan harus ada urgensi yang menjadi dasar dalam pengaturan lex specialis sehingga mengesampingkan lex generalis. Penenggelaman/pembakaran kapal tidak memiliki urgensi yang harus segera mungkin dilaksanakan sehingga tidak dapat menunggu proses adjudkasi dan adanya putusan pengadilan yang berkekuatan hukum tetap. Urgensi dari penenggelaman/pembakaran kapal yang merupakan punishment yang sangat keras adalah untuk memberikan efek jera kepada pelaku dan mencegah adanya illegal fishing kembali sehingga menegakkan kedaulatan wilayah perairan di wilayah NKRI. Penenggelaman/pembakaran kapal dilakukan secara langsung pada saat penangkapan hanya dapat dibenarkan apabila adanya manuver atau perlawanan pada saat penangkapan sehingga dapat membahayakan kepada penyidik dan/atau pengawas perikanan dapat melakukan suatu diskresi yang terukur dan bertanggungjawab untuk melakukan penenggelaman secara langsung dengan tetap menjunjung hak asasi manusia.

Penenggelaman/Pembakaran kapal seharusnya dilakukan melalui sistem peradilan pidana yang diatur dalam KUHAP. Penyidik hanya berwenang melakukan penyidikan kemudian melimpahkan perkara kepada Penuntut Umum untuk selanjutnya dilakukan penunutan kemudian hakim mengadila lalu menjatuhkan pidana apabila pelaku telah terbukti secara sah dan meyakinkan bersalah. Penyidik sesuai dengan ketentuan Pasal 7 Ayat (1) huruf d dan Pasal 38 KUHAP dapat melakukan penyitaan terhadap kapal tersebut yang merupakan benda yang digunakan untuk melakukan tindak pidana sehingga dapat dilakukan penyitaan sebagaimana ketentuan dalam Pasal 39 Ayat (1) huruf b KUHAP. Ketentuan Pasal 45 Ayat (4) Jo. Pasal 46 Ayat (1) huruf c KUHAP mengatur bahwa benda sitaan yang bersifat terlarang atau dilarang untuk diedarkan atau diperoleh atau digunakan untuk melakukan tindak pidana tidak dikembalikan kepada yang berhak/pemiliki melainkan dirampas untuk dipergunakan bagi kepentingan negara atau untuk dimusnahkan. Berdasarkan ketentuan tersebut maka Penuntut Umum dalam tuntutannya dapat menununtut agar kapal yang dipergunakan untuk melakukan tindak pidana yang telah disita sebelumnya agar dirampas untuk dimusnahkan yang nantinya akan dilakukan dengan cara ditenggelamkan/dibakar dengan tujuan untuk memberikan efek jera kepada pelaku sehingga Majelis Hakim dalam putusannya akan menetapkan barang bukti berupa kapal tersebut dirampas untuk dimusnahkan sehingga dengan adanya penenggelaman/pembakaran kapal yang dilakukan melalui proses adjudikasi terlebih dahulu dapat mewujudkan kemanfaatan untuk memberikan efek jera kepada pelaku dan menjaga kedaulatan wilayah perairan NKRI dapat tercapai serta keadilan dan kepastian hukum terhadap pelaku. Permasalahan akan terjadi apabila kapal tersebut telah ditenggelamkan/dibakar terlebih dahulu sebelum adanya putusan pengadilan yang berkekuatan hukum tetap namun putusan pengadilan menetapkan bahwa barang bukti berupa kapal tersebut tidak dirampas untuk dimusnahkan melainkan dirampas untuk digunakan bagi kepentingan negara sehingga tidak sepantasnya 
pembakaran/penenggelaman kapal dilakukan tanpa berdasarkan putusan pengadilan yang berkekuatan hukum tetap.

Pengaturan mengenai syarat-syarat dalam penenggelaman/ pembakaran kapal memang saat ini telah diatur dalam Permenkkp 37/2017 sehingga syarat-syarat tersebut merupakan diskresi yang diberikan kepada penyidik dan/atau pengawas perikanan, namun tidak sepantasnya syarat tersebut diatur dalam Peraturan Menteri melainkan harus dalam UU 45/2009 oleh karena terkait dengan perampasan hak seseorang sehingga termasuk sebagai materi muatan undang-undang sebagaimana yang diatur dalam Pasal 10 Ayat (1) UU 12/2011 bukan merupakan materi muatan dari Peraturan Menteri. Penulis sependapat terhadap diskresi yang berikan kepada penyidik dan/atau pengawas perikanan untuk melakukan penenggelaman/pembakaran kapal pada saat terjadinya operasi tangkap tangan/tertangkap tangan apabila adanya manuver dari pelaku pada saat ditangkap sehingga membahayakan penyidik pada saat melakukan penangkapan namun diskresi tersebut harus diatur dalam UU 45/2009 yang mana diskresi dilakukan dengan selaras yang mengharuskan untuk dilakukan, patut, masuk akal, adanya keadaan yang memaksa, dan menhormati hak asasi manusia sebagaimana halnya syarat untuk melakukan diskresi penyelidik dan penyidik Polri yang diatur dalam Pasal 16 Ayat (2) UU 2/2002 sehingga tidak dilakukan secara sewenang-wenang.

\subsection{Kewenangan Jaksa Dalam Eksekusi Pembakaran/Penenggelaman Kapal Tindak Pidana Illegal Fishing Berbendera Asing}

Pemberian kewenangan kepada penyidik dan/atau pengawas perikanan untuk melakukan penenggelaman/pembakaran kapal secara langsung tanpa adanya putusan pengadilan sebagaimana diatur dalam UU 45/2009 merupakan hal yang salah sebagaimana telah diuraikan di atas. Perkembangan saat ini Susi Pudjiastuti selaku Menteri KP pada tanggal 5 Mei 2019 mengemukakan bahwa sebanyak 13 kapal telah ditenggelamkan di Pontianak yang mana terdapat 51 kasus yang sudah berkuatan hukum tetap dan masih ada 90 kasus dalam proses banding serta kasasi yang mana apabila telah berkekuatan hukum tetap maka 90 kapal tersebut akan ditenggelamkan. ${ }^{22}$ Kebijakan tersebut membuktikan bahwa adanya kekeliruan dalam kewenangan penenggelaman/pembakaran kapal yang diberikan kepada penyidik tanpa adanya putusan pengadilan sehingga meskipun dalam UU 45/2009 memberikan kewenanagan untuk melakukan penenggelaman/pembakaran kapal secara langsung, namun saat ini kewenangan tersebut sudah tidak digunakan lagi.

Penenggelaman/pembakaran kapal saat ini yang dilakukan dengan berdasarkan pada putusan pengadilan yang berkekuatan hukum tetap merupakan suatu tindakan yang benar, namun disisi lain masih terdapat kekeliruan dalam tindakan yang dilakukan tersebut di atas yakni penenggelaman/pembakaran kapal tersebut dilakukan oleh KKP yang merupakan penyidik PNS dalam tindak pidana illegal fishing. SPP mengenal 4 komponen subsistem yakni, Kepolisian / Penyidik Pegawai Negeri Sipil, Kejaksaan, Pengadilan dan Lembaga Pemasyarakatan dengan fungsi masing-masing saling terkait

22 Tim detikcom. (2019). 13 Kapal Asing Pencuri Ikan Ditenggelamkan di Pontianak. URL: http:// https://news.detik.com/berita/d-4536307/13-kapal-asing-pencuri-ikanditenggelamkan-di-pontianak. (diakses 13 Mei 2020). 
dan melengkapi. ${ }^{23}$ Komponen SPP tersebut mengalami perkembangan oleh karena Advokat yang mendampingi terdakwa yang mengakibatkan advokat juga termasuk sebagai salah satu komponen dalam SPP sehingga terdapat 5 komponen dalam SPP. ${ }^{24}$ KUHAP dan undang-undang masing-masing komponen telah mengatur secara jelas mengenai tugas pokok dan fungsi masing-masing komponen sehingga dapat terlaksananya SPP dari ditemukannya suatu tindak pidana hingga eksekusi terhadap putusan pengadilan yang telah berkekuatan hukum tetap.

Pasal 1 angka 1 dan 2 Jo. Pasal 6 Ayat (1) huruf b Jo. Pasal 7 Ayat (1) KUHAP memberikan kewenangan kepada penyidik PNS untuk melakukan penyidikan terhadap tindak pidana yang mana dalam penyidikan tersebut tidak terdapat kewenangan untuk melakukan eksekusi terhadap putusan pengadilan. Pasal 30 Ayat (1) UU 16/2004, diatur bahwa Kejaksaan bertugas dan berwenang melakukan penuntutan dan melaksanakan penetapan hakim dan mengeksekusi putusan pengadilan yang berkekuatan hukum tetap. Pasal 1 butir 6a KUHAP Jo. Pasal 1 butir 1 UU 16/2004, diatur bahwa Jaksa merupakan pejabat yang memiliki wewenang sebagai penuntut umum dan melaksanakan putusan pengadilan yang berkekuatan hukum tetap serta wewenang lainnya berdasarkan undang-undang. Berdasarkan tugas pokok dan fungsi Jaksa dalam SPP, maka kewenangan untuk melakukan eksekusi tindak pidana apapun termasuk tindak pidana illegal fishing untuk menenggelamkan/membakar kapal tersebut adalah kewenangan jaksa selaku penuntut umum dan bukan merupakan kewenangan penyidik tindak pidana illegal fishing yakni KKP sebagai penyidik PNS. KKP yang melakukan eksekusi terhadap putusan pengadilan tindak pidana illegal fishing mengenai penenggelaman/pembakaran kapal selama ini telah bertentangan dengan SPP yang ada oleh karena eksekusi tersebut bukan merupakan kewenangan KKP selaku penyidik PNS.

Kebijakan hukum pidana illegal fishing dimasa yang akan datang agar sesuai dengan SPP, maka apabila adanya laporan atau tertangkap tangan terjadinya illegal fishing maka Kementerian KKP selaku penyidik PNS melakukan penyidikan yang diantaranya melakukan penyitaan terhadap kapal yang digunakan oleh tersangka kemudian melimpahkan perkara kepada Jaksa untuk melakukan penuntutan yang dalam tuntutannya meminta majelis hakim agar menetapkan untuk kapal yang dilakukan untuk melakukan tindak pidana untuk dirampas untuk dimusnahkan yang dapat dilakukan dengan cara ditenggelamkan/dibakar yang kemudian Majelis Hakim dalam putusannya menetapkan bahwa kapal tersebut dirampas untuk dimusnahkan sesuai dengan tuntutan penuntut umum. Putusan pengadilan yang telah berkuatan hukum tetap kemudian diajadikan dasar oleh Jaksa selaku penuntut umum untuk melakukan eksekusi untuk memusnahkan kapal dengan cara ditenggelamkan/dibakar yang mana dalam melaksanakan eksekusi tersebut dapat melakukan kordinasi dan mengundang pihak terkait diantaranya Kementerian KKP selaku penyidik PNS.

${ }^{23}$ Rezafaraby, (2016). Tinjauan Pengaturan dan Permasalahan Dalam Sistem Peradilan Pidana Indonesia Menuju Sistem Peradilan Pidana Terpadu, Jurnal Perencanaan Pembangunan, Edisi 01, h. 81

${ }^{24}$ Rozi, M. M. (2017). Peranan advokat sebagai penegak hukum dalam sistem Peradilan pidana dikaji menurut undang-undang Nomor 18 tahun 2003 tentang advokat. Jurnal Hukum Mimbar Justitia, 1(2), 628-647., h.630. 
Kebijakan hukum pidana illegal fishing yang telah dilakukan tersebut tentu sesuai dengan SPP di Indonesia dan kemanfaatan, keadilan, dan kepastian hukum dalam penegakkan hukum terhadap tindak pidana illegal fishing dapat tercapai secara selaras.

\section{Kesimpulan}

Kewenangan penyidik untuk melaksanakan pembakaran/penenggelaman kapal tindak pidana illegal fishing berbendera asing secara langsung tanpa putusan pengadilan yang berkekuatan hukum tetap merupakan tindakan yang bertentangan dengan Pasal 28D Ayat (1) UUDNRI 1945 dan tidak sesuai dengan SPP yang ada di Indonesia yang menerapkan DPM dan CCM secara ideal. Kewenangan tersebut telah merampas hak tersangka/terdakwa yang diatur di KUHAP sehingga tidak memberikan keadilan dan kepastian hukum yang mana seharusnya penenggelaman/pembakaran kapal dilakukan berdasarkan putusan pengadilan yang berkekuatan hukum tetap. KKP selaku penyidik PNS dalam tindak pidana illegal fishing tidak berwenang untuk melakukan eksekusi penenggelaman/pembakaran kapal tindak pidana illegal fishing berbendera asing. SPP di Indonesia telah mengatur bahwa kewenangan untuk melakukan eksekusi terhadap putusan pengadilan yang berkekuatan hukum tetap termasuk diantaranya pemusnahan kapal sebagai benda sitaan yang dipergunakan untuk melakukan tindak pidana illegal fishing merupakan kewenangan Jaksa selaku penuntut umum sehingga penenggelaman/pembakaran kapal harus dilaksanakan oleh Jaksa sekalu eksekutor. Dan sebagai saran dari penulis Agar Pemerintah bersama DPR RI segera melakukan revisi terhadap UU 45/2009 dengan mencabut kewenangan Penyidik untuk melakukan penenggelaman/pembakaran kapal secara langsung. Agar Jaksa selaku eksekutor dalam penenggelaman/pembakaran kapal dalam melakukan eksekusi melakukan kordinasi dan turut mengundang penyidik PNS dan pengawas perikanan sebagai saksi dalam melakukan eksekusi.

\section{Daftar Pustaka}

\section{Buku}

Achmad Ali, (2002). Menguak Tabir Hukum: Suatu Kajian Filosofis dan Sosiologis. Jakarta: Gunung Mas.

Adji, S. (2015). Perkembangan dan Permasalahan Hukum Indonesia. Jakarta: Diadit Media.

Agus Susanto, (2014). Hukum, Moral dan Keadilan. Jakarta: Prenada Media.

Amirudin dan Zainal Asikin. (2012). Pengantar Metode Penelitian Hukum, Jakarta: Rajawali Pers.

Mahmudah N. (2015). Illegal Fishing Pertanggungjawaban Pidana Korporasi di Wilayah Perairan Indonesia. Jakarta: Sinar Grafika.

Nurul Qamar. (2010). Hukum Itu Ada Tapi Harus Ditemukan. Makassar: Pustaka Refleksi.

Sukriono, D. (2010). Hukum, Konstitusi dan Otonomi. Malang: Setara Press.

\section{Jurnal}

Ali, M. (2007). Sistem Peradilan Pidana Progresif; Alternatif dalam Penegakan Hukum Pidana. Jurnal Hukum Ius Quia Iustum, 14(2).

Barama, M. (2016). Model Sistem Peradilan Pidana Dalam Perkembangan. Jurnal Ilmu Hukum, 3(8), 8-17. 
Bo'a, F. Y. (2018). Pancasila sebagai Sumber Hukum dalam Sistem Hukum Nasional. Jurnal Konstitusi, 15(1), 21-49.

Fernandes, I. (2017). Tinjauan Yuridis Illegal Fishing di Indonesia Berdasarkan Undang-Undang Perikanan. Jurnal Hukum Respublica, 17(1), 189-209.

Haryanto, H., \& Setiyono, J. KEBIJAKAN PENENGGELAMAN KAPAL ASING PELAKU ILLEGAL FISHING OLEH PEMERINTAH INDONESIA DALAM PERSFEKTIF HUKUM PIDANA INTERNASIONAL. LAW REFORM, 13(1), 7085.

Nasirin, C., \& Hermawan, D. (2017). Kontroversi Implementasi Kebijakan Penenggelaman Kapal Dalam Rangka Pemberantasan Illegal Fishing di Indonesia. Spirit Publik, 12(1), 9-24.

Putri, H. M., Pramoda, R., \& Firdaus, M. (2018). Kebijakan Penenggelaman Kapal Pencuri Ikan Di Wilayah Perairan Indonesia Dalam Perspektif Hukum. Jurnal Kebijakan Sosial Ekonomi Kelautan dan Perikanan, 7(2), 91-102.

Rahman, Z., \& Republik, N. K. (2015). Penenggelaman Kapal Sebagai Usaha Memberantas Praktik Illegal Fishing. Rechts Vinding Online,(Januari, 2015).

Rozi, M. M. (2017). Peranan advokat sebagai penegak hukum dalam sistem Peradilan pidana dikaji menurut undang-undang Nomor 18 tahun 2003 tentang advokat. Jurnal Hukum Mimbar Justitia, 1(2), 628-647.

Saraswati, D. A., \& Setiyono, J. Yurisdiksi Kriminal Negara Dalam Penenggelaman Kapal Pelaku Tindak Pidana Illegal Fishing Di Perairan Indonesia. Law Reform, 13(2), 180-188.

\section{Online/World Wide Web}

Elviana Roza. (2017). Maritim Indonesia, Kemewahan Yang Luar Biasa. URL: http:/ / www2.kkp.go.id/artikel/2233-maritim-indonesia-kemewahan-yang-luarbiasa. (diakses 05 September 2019).

Pasopati, G. (2019). Setahun jadi Menteri Susi Tenggelamkan Kapal Tanpa Diadili. URL: $\quad$ https://www.cnnindonesia.com/ekonomi/20151020121906-9286037/setahun-jadi-menteri-susi-tenggelamkan-kapal-tanpa-diadili, diakses 29 Juni 2019.

Budi Prasetyo. (2019) Laut Indonesia Dapat Menyumbang Pendapatan 1,2 Triliun Dollar

AS.URL:https://www.kompas.com/ekonomi/read/2014/08/11/133800526/La ut.Indonesia.Dapat.Menyumbang.Pendapatan.1.2.Triliun.Dollar.AS (Diakses 29 Juni 2019).

Tim detikcom. (2019). 13 Kapal Asing Pencuri Ikan Ditenggelamkan di Pontianak. URL: http:// https://news.detik.com/berita/d-4536307/13-kapal-asingpencuri-ikan-ditenggelamkan-di-pontianak. (diakses 13 Mei 2020).

Wiji. (2019). Menteri Susi: Kerugian Akibat Illegal Fishing Rp 240 Triliun. URL: https://m.detik.com/finance/berita-ekonomi-bisnis/d-2764211/menteri-susikerugian-akibat-illegal-fishing-rp-240-triliun, diakses 29 Juni 2019.

\section{Peraturan Perundang-Undangan}

Undang-Undang Dasar Negara Republik Indonesia Tahun 1945.

Kitab Undang-Undang Hukum Pidana. 
Undang-Undang Republik Indonesia Nomor 8 Tahun 1981 tentang Hukum Acara Pidana (Lembaran Negara Republik Indonesia Tahun 1981 Nomor 76, Tambahan Lembaran Negara Republik Indonesia Nomor 3209).

Undang-Undang Republik Indonesia Nomor 2 Tahun 2002 tentang Kepolisian Negara Republik Indonesia (Lembaran Negara Republik Indonesia Tahun 2002 Nomor 2, Tambahan Lembaran Negara Republik Indonesia Nomor 4168).

Undang-Undang Republik Indonesia Nomor 16 Tahun 2004 Tentang Kejaksaan Republik Indonesia (Lembaran Negara Republik Indonesia Tahun 2004 Nomor 67, Tambahan Lembaran Negara Republik Indonesia Nomor 4401).

Undang-Undang Republik Indonesia Nomor 45 Tahun 2009 tentang Perubahan Atas Undang-Undang Republik Nomor 31 Tahun 2004 tentang Perikanan (Lembaran Negara Republik Indonesia Tahun 2009 Nomor 154, Tambahan Lembaran Negara Republik Indonesia Nomor 5073).

Undang-Undang Republik Indonesia Nomor 12 Tahun 2011 tentang Pembentukan Peraturan Perundang-Undangan (Lembaran Negara Republik Indonesia Tahun 2011 Nomor 82, Tambahan Lembaran Negara Republik Indonesia Nomor 5234).

Surat Edaran Mahkamah Agung Republik Indonesia Nomor 1 Tahun 2015 tentang Barang Bukti Kapal dalam Perkata Pidana Perikanan.

Peraturan Menteri Kelautan dan Perikanan Republik Indonesia Nomor 37/PERMENKP/2017 tentang Standar Operasional Prosedur Penegakan Hukum Satuan Tugas Pemberantasan Penangkapan Ikan Secara Ilegal (Illegal Fishing). 